\title{
Luto e escrita no diário de Walmir Ayala
}

\author{
Daniele Ribeiro Fortuna*
}

\begin{abstract}
Difícil é o reino, ninguém atinge os cavalos e os férteis campos sem que isto lhes signifique uma custosa renúncia. [...] Difícil é o reino da solidão, o que começa assim.
\end{abstract}

Walmir Ayala

\section{Introdução}

A morte é uma das poucas - talvez a única - certezas da vida. Esta frase já se tornou um clichê, que repetimos várias vezes, por diversos motivos. Quando a usamos, falamos da morte de forma corriqueira, como se fosse um fato comum, cotidiano. Embora realmente o seja, já que, todos os dias, milhares de pessoas morrem no mundo, a maneira de encarar a morte hoje nada tem de tranquila.

Mais do que negá-la, tentamos torná-la invisível. A morte tornou-se tabu, um assunto proibido, que deve ser evitado a qualquer custo e, principalmente, com quem está prestes a encará-la. Atualmente, vivemos como se não fôssemos morrer e, quando a morte se aproxima em função de uma doença grave, por exemplo, todos a nossa volta agem como se se tratasse de um mal passível de cura. Até os últimos momentos, procura-se mascarar a realidade e, quando ela se mostra inevitável, ouvimos as frases feitas de consolo, parecidas com a que abrimos este texto: "descansou", "agora está em paz", "estava sofrendo muito e foi melhor assim".

A morte é um tema difícil de encarar, sempre visto como o contrário da vida, o problema para o qual não há solução. Embora, às vezes, morbidamente fascinante, procuramos mantê-la distante de nós. Com os outros e os seus, podemos até vislumbrá-la, em determinadas situações, conosco e os nossos, tapamos nossos olhos.

Por isso, talvez o diário do escritor Walmir Ayala provoque incômodo. A obra está dividida em três volumes, nos quais um dos temas principais é a morte: a sua, a de sua mãe e a de conhecidos. Em praticamente todas as páginas, há algum tipo

Doutora em Literatura Comparada e professora da Universidade do Grande Rio (Unigranrio), Rio de Janeiro, RJ, Brasil. E-mail: drfortuna@hotmail.com 
de referência à morte: uma obsessão que ora o escritor nega, ora quer receber de braços abertos.

Este artigo aborda a morte no diário de Ayala, que a conheceu muito novo, quando, aos quatro anos, perdeu sua mãe. A perda marcaria sua vida e influenciaria seu trabalho. Como Barthes (2011), que escreveu um diário de luto após a morte de sua mãe, Walmir também vive seu luto na escrita. Mas, ao contrário da literatura de Barthes, minimalista e silenciosa (CHIARA, 2014), a de Ayala se revela no excesso. Nesse sentido, sua relação com a morte parece ser de abjeção - uma relação ambígua de fascínio e repulsa (KRISTEVA, 1982). Há também uma espécie de consolo pela perda da mãe e pelas lacunas que existem em sua vida que só se concretiza por meio da escrita.

Poeta, crítico literário, dramaturgo, Walmir Ayala tem uma extensa obra, atualmente pouco conhecida do grande público. Seu diário foi publicado em três volumes, cobrindo o período de tempo entre 1956 e 1961: Difícil é o reino - Diário I (1962); O visível amor - Diário II (1963); e A fuga do Arcanjo - Diário III (1976).

Neste texto, começaremos apresentando uma breve discussão sobre o diário, para, em seguida, nos determos sobre a vida do escritor Walmir Ayala. Posteriormente, abordaremos a questão da morte atualmente e da abjeção, para, finalmente, nos determos em seus diários.

\section{Diário: uma garrafa lançada ao mar}

Philippe Lejeune (2014) considera que o diário é como uma garrafa lançada ao mar: uma forma de fixar o passado, podendo, certa forma, revê-lo no futuro. Para Leonor Arfuch (2010, p. 143), o diário "promete a maior proximidade à profundidade do eu". Nesse sentido, a autora comenta ainda que o diário aponta mais para o íntimo e menos para o biográfico, já que seus autores, constantemente, abordam questões envolvendo sentimentos como medo, angústia, além de sua relação com o erotismo. Arfuch ainda afirma que "Como lugar de memória, o diário se aproxima do álbum de fotografias [...], cuja restituição da lembrança, talvez mais imediata e fulgurante, solicita também um trabalho à narração" (ARFUCH, 2010, p. 145).

Trata-se de um texto aberto ao improviso, mas com algumas marcas fundamentais que o caracterizam. Lejeune aponta a principal: a datação do texto - sem a qual, os escritos se tornariam uma simples caderneta - centrada no presente e com conteúdo que não sofreu posteriores mudanças.

De acordo com Lilian de Lacerda (2003, p. 45), "a utilização de datas e sua configuração em destaque no corpo do texto, a explicitação e, muitas vezes, a repetição de lugares, pessoas e situações conferem ao texto uma certa sequência e ao registro uma rotina - a escrita do cotidiano". Lilian considera também que "os diários são constituídos de textos em geral compactos, de informações breves e mais ou 
menos contínuas, e por isso as anotações se associam umas às outras, mas são, ao mesmo tempo, relativamente independentes" (LACERDA, 2003, p. 45).

Já Lejeune (2014) apresenta as funções do diário. Para ele, o diário tem como objetivos conservar a memória, ajudar o diarista a sobreviver, permitir o desabafo, o autoconhecimento, a resistência, o refúgio, a reflexão e, finalmente, a prática da escrita. O diário possibilita ao escritor viver de forma mais harmoniosa, fixando o passado e confessando seus problemas, inquietações e segredos. Com isso, tornase um confidente; em suas linhas, "o eu escapa momentaneamente à pressão social, se refugia protegido em uma bolha onde pode se abrir sem risco, antes de voltar, mais leve, ao mundo real" (LEJEUne, 2014, p. 303). Outro papel fundamental do diário é que ele se constitui como um objeto de ação: quando refletimos sobre os problemas que nos afligem, conseguimos chegar mais facilmente a soluções, o que nos fortalecem diante das intempéries da vida.

E é dessa forma que Ayala fazia uso do seu diário: um espaço de desabafo, de reflexão, mas também de conservação de memória.

\section{Um pouco sobre Walmir Ayala}

Embora Lejeune (2014) considere que, ao lermos uma autobiografia ou um diário, não importa muito se o que está escrito corresponde(u) à realidade, já que é travado com o leitor um pacto referencial - o qual significa que o texto autobiográfico não se propõe "a fornecer informações a respeito de uma 'realidade' externa ao texto e a se submeter portanto a uma prova de verificação (LEJEUNE, 2014, p. 43, grifo do autor) -, nem sempre é possível dissociar a obra da vida de seu autor. Cabe aqui recorrermos a Foucault (1992, p. 143), segundo o qual "o papel da escrita é constituir, com tudo o que a leitura constituiu, um 'corpo'”. E este corpo seria o "próprio corpo daquele que, ao transcrever as suas leituras, se apossou delas e fez a sua a respectiva verdade: a escrita transforma a coisa vista ou ouvida em 'forças de sangue'”.

Nesse sentido, para refletir sobre os diários de Walmir Ayala, é importante conhecer um pouco da história de seu autor. Walmir Félix Solano Ayala nasceu em Porto Alegre, no Rio Grande do Sul, em 4 de janeiro de 1933. Seu pai, Sylvio Solano Ayala, era mecânico de automóveis e, desde cedo, incentivava o filho a estudar. A mãe, Letterina Riccardi Ayala, faleceu quando Ayala tinha apenas quatro anos. A morte de sua mãe o marcaria para sempre, influenciando-o, inclusive, a escrever: "Comecei a fazer poemas muito cedo, como compensação do diálogo interrompido com as pessoas que me rodeavam. A morte de minha mãe na primeira infância foi a raiz de tudo. Acho que foi pela oração que cheguei à poesia, contri- 
ção solitária que me impediu de cair no poço para sempre." (Ayala, documento. 28, p. 4-5, apud PaIXÃO, 2011, p. 32). ${ }^{1}$

O início da carreira literária de Ayala foi em Porto Alegre, onde começou a cursar Filosofia. Seu primeiro livro, $A$ face dispersa, foi publicado aos 23 anos com a ajuda do pai que, na verdade, queria desestimulá-lo a ser escritor. O pai de Walmir acreditava que, com o fracasso do livro, o filho desistiria da profissão. Mas foi em vão. Ayala abandonou a universidade e se mudou para o Rio de Janeiro. Lá atuou em diversos veículos da imprensa carioca, como fornal do Brasil, Tribuna da Imprensa, Diário de Notícias, fornal do Commercio, Diário Carioca. Sua carreira como escritor foi profícua: publicou mais cem obras (PAIXÃo, 2011), de diversos gêneros literários - literatura infantil, teatro, poesia, romance etc.

Apesar de ter sido um intelectual com uma vasta obra e de fundamental importância no cenário literário brasileiro e de ter recebido inúmeros prêmios, trabalho ainda é pouco explorado. Sobre isso o próprio Ayala afirmou:

Tenho a felicidade de permanecer em uma geração ainda não codificada. Em geral os analistas saltam da geração de 45 para o Concretismo/ Neoconcretismo/ vanguardas afins, e daí para o tropicalismo e outros movimentos de curto fôlego. Como situar este grupo de poetas que trabalhou, e muito, paralelamente ao surgimento do concretismo, enraizado no segundo qüinqüênio da década de 50? Poetas surgidos por volta de 1955 , 1956, e entre os quais incluo Lélia Coelho Frota, Foed Castro Chamma, Octávio Mora, Marli de Oliveira. Ficamos todos no limbo. Assis Brasil corajosamente denominou de "A Geração da Imagem", mas a especulação não foi aprofundada e está pedindo atenção. Um desafio talvez aos críticos historicistas, já que não podem nos negar, nem à tensão da nossa presença e do nosso ofício. Coloco esta questão já que uma certa leviandade campeia, ou talvez a omissão causada pela dificuldade de enquadrar os poetas citados na linearidade de uma evolução (AyALA, documento 28, p. 6 apud PAIXÃO, 2011, p. 27)

Como Ayala aponta, foi reconhecido pelo crítico Assis Brasil como pertencente à Geração da Imagem, uma geração para a qual a imagem tinha um importante papel no texto literário. Talvez venha daí também o interesse do escritor pelas artes plásticas, já que o seu trabalho apresenta uma forte influência da imagem. Em seu diário, por exemplo, são inúmeras as descrições de imagens, como veremos mais adiante, quando o poeta se refere à morte da mãe de Lúcio Cardoso e ao cadáver de uma mulher de nome Checa.

1 Esta citação foi retirada da dissertação de mestrado de Roseane Cristina da Paixão, a qual compilou documentos sobre a biografia de Walmir Ayala: "artigos de jornais, entrevistas sobre o autor e por ele concedidas a terceiros, cópias de alguns originais, muitos dos quais sem referências, cedidas gentilmente pelos guardiões do acervo de Ayala na Casa de Cultura Walmir Ayala, sediada na cidade de Saquarema, no Rio de Janeiro" (PAIxÃo, 2011, p. 28). 
De acordo com Paixão (2011), seu trabalho como crítico - tanto literário, quanto teatral e de artes plásticas - possibilitou a Ayala viajar para diversos países. São essas experiências, aliadas a acontecimentos do seu cotidiano, a base da sua carpintaria literária. Entretanto, o escritor transformava o banal em insólito, buscando provocar no leitor algum tipo de sensação.

Assim, embora fosse uma escrita dividida em fragmentos por datas, tais fragmentos traziam reflexões, descrições, narrativas capazes de despertar sentimentos - angústia, desalento e até mesmo pena de um jovem que parece sempre desamparado. Nesse sentido, seus diários não estão alijados da sua produção poética. Da mesma forma como trata temas do cotidiano, aborda questões que são recorrentes na sua poesia, como amor, solidão e morte.

Homossexual assumido, Walmir Ayala tratou sobre o assunto em seu diário, no final da década de 1950 e início dos anos 6o. Abordou-o tema em outras obras. Entretanto, em seu diário, é possível perceber, como veremos adiante, que embora assumisse sua orientação sexual, não era uma condição exatamente tranquila para o escritor: Ayala se mostra assombrado por sonhos e pensamentos de culpa e autopunição.

Depois de muitos anos no Rio de Janeiro, Ayala resolveu se mudar para a cidade de Saquarema, no litoral do estado do Rio de Janeiro. O escritor passou a se dividir entre o Rio e Saquarema. Viveu lá muitos anos com seu filho adotivo, Gustavo Adolfo Cox. Em 1989, aos 19 anos, Gustavo se suicidou. Em agosto de 1991, Walmir Ayala faleceu após sofrer um infarto. A vida do escritor foi marcada por essas duas grandes perdas - a de sua mãe e a de seu filho.

No seu diário, escrito quando o autor tinha entre 23 e 28 anos, é possível perceber claramente como a morte da mãe o afetou. Ayala parece viver um luto tardio, talvez eterno. Talvez ainda a sua orientação sexual também o fizesse pensar na morte como uma opção para uma vida de decepções amorosas e preconceitos na sociedade do final da década de 1950.

Ayala fala sobre a morte num momento em que o assunto já gerava desconforto. Trata-se de um namoro proibido com a morte, no qual há atração, medo, afastamento e até repulsa. Antes de analisarmos essa relação, porém, cabe refletirmos sobre a morte e o abjeto.

\section{Um pouco sobre Walmir Ayala}

A visão que o homem tem sobre a morte foi se modificando com o tempo. $\mathrm{Na}$ Idade Média, a morte era vivida de maneira coletiva e comunitária. Ela deveria ser pública, de maneira que "o lugar dos mortos era aquele em que se vivia. O cemitério, o centro da vida social” (RoDRIGUes, 1983, p. 125). Havia uma convivência tranquila entre o profano e o sagrado. De acordo com Rodrigues (1983), os cadáve- 
res, geralmente, estavam mal enterrados, exumados, expostos, e isso não causava nojo ou qualquer tipo de desconforto. A convivência com os mortos e seus corpos era natural.

As pessoas podiam se preparar para a morte, pois ela se fazia anunciar. Segundo Ariès (2013), naquela época, acreditava-se no aviso da morte, por meio de sonhos ou premonições, o que permitia que o moribundo reunisse a família para se despedir, aconselhar ou tomar as providências que julgasse necessárias antes de sua partida. Esta morte prenunciada era a "ideal". A morte súbita, ocorrida de forma repentina, era vista como vergonhosa.

A morte era considerada como um processo natural da vida. Acreditava-se na ressurreição da carne e, portanto, na continuidade da existência. Obviamente, como afirma Ariès (2013), havia um desgosto, um certo sofrimento, mas nada insuportável. Também não havia temor. A atitude era de resignação. Morrer era um processo conduzido pelo próprio moribundo: ele sabia que seu fim estava próximo e, embora tudo fosse vivenciado com a família, as decisões cabiam a ele.

Aproximadamente no século XV, morrer adquiriu um sentido dramático que antes não possuía. Este sentido dramático toma contornos ainda mais contundentes nos séculos XVI e XVII. A morte passa a ser vista como o fim de uma biografia, de uma sequência de eventos (RoDrigues, 1983). Principalmente para a burguesia, passa a existir também uma ideia de posse e conservação: se antes o cadáver pertencia à comunidade e poderia, inclusive, estar presente durante festejos realizados nos cemitérios, agora ele se tornava propriedade. Não apenas o corpo deveria ter um destino definido, como este destino se relacionava com a "apropriação do lugar e do indivíduo” (Urbain, p. 145 apud Rodrigues, 1983, p. 138). Tal mudança se deve à consciência de si e do seu corpo que surgiram com o individualismo. Com isso, se um ser é único, seu corpo também o é e, portanto, o fim de uma vida gera um intenso sofrimento: a partida de alguém sem igual, com uma história particular.

Outra mudança importante é que as decisões sobre a morte passam a ser responsabilidade da família. Se antes o indivíduo decidia sobre tudo relativo à sua morte - testamento, túmulo, providências a serem tomadas etc. -, agora cabe à família tomar tais decisões. A morte se torna menos pública: antes toda comunidade testemunhava seus últimos momentos; agora somente a família podia presenciá-los. E esse momento se revela muito mais dramático, desesperador e sofrido.

Todo esse panorama resultou na concepção atual da morte. Ariès (2013, p. 756, grifo do autor) considera que: "Dois traços saltam aos olhos do menos atento dos observadores: a novidade, certamente o caráter de oposição a tudo o que precedera, de que é a imagem invertida, o negativo: a sociedade expulsou a morte, salvo a dos homens de Estado".

A morte tornou-se algo que deve ser evitado, negado, ignorado. Passamos a viver como se ela não existisse. Mudou também a postura do médico e da família. 
O paciente com o diagnóstico de uma doença fatal deve ignorar seu estado até os últimos minutos, para morrer sem sentir: "O 'não se sentir morrer' substituiu o 'sentindo a morte próxima”" (ARIÈs, 2013, p. 759).

O funeral acontece de forma discreta, ao qual comparecem apenas os familiares e amigos mais íntimos. Esta transformação do morrer implica também uma mudança no luto, que é rejeitado e suprimido. Os que ficam devem viver sua dor em silêncio, sem manifestá-la em público: "O luto é uma doença. Aquele que o demonstra prova fraqueza de caráter” (ARIÈs, 2013, p. 782).

Assim, morte e luto são assuntos a serem esquecidos a qualquer custo. Silenciar sobre a morte é a tentativa de esquecer que também nós, um dia, vamos morrer, pois, como afirma Rodrigues (1983, p. 93): "A morte do outro é o anúncio e a prefiguração da morte de 'si', ameaça da morte em 'nós'."

Ana Chiara (2001, p. 52) considera que "somos impedidos de pensar na morte, pois seu vazio não se confunde com o Nada, sendo esse a plenitude de uma negação, enquanto aquele impede o pensamento - é vazio de matéria". Encarar esse vazio acarreta medo. Receamos perder o que temos de único na vida: a nossa individualidade e o convívio com aqueles que amamos, que são, para nós, insubstituíveis.

Apesar de tentarmos ignorá-la, a morte, misteriosa, impactante e - para alguns - sedutora pode provocar fascínio. Ela nos coloca em contato com o que mais tememos e com o que há de mais frágil em nós. Diante dela, não há subterfúgios. Podemos não querer olhar, mas ela está lá.

Enquanto alguns procuram a todo custo fugir da morte, mesmo quando ela atravessa a vida - pela perda de alguém ou pela ameaça de uma doença fatal -, outros buscam o contato com ela, seja por meio de um pensamento fixo, da escrita sobre a morte ou até mesmo através de uma atitude mais radical, como o suicídio.

A morte tem um inegável caráter abjeto, ainda que, atualmente, se busque tornála sem sentido nenhum. Mesmo assim, a morte é um fantasma que sempre volta a nos assombrar, com as suas armadilhas abjetas. Julia Kristeva (1982) define o abjeto como aquilo do qual é preciso se livrar para se tornar um "eu". E esse "algo"a ser expelido é uma substância fantasmagórica, ao mesmo tempo estranha e íntima do sujeito, cuja proximidade provoca pânico. Segundo a autora, embora esteja tão perto, não pode ser assimilado (SANTOS, 2007).

O abjeto faz com que o indivíduo atente para a fragilidade das suas próprias fronteiras, percebendo sua condição problemática e provisória. Em francês, o termo é muito mais forte, porque, nessa língua, significa algo realmente repulsivo. Kristeva (1997 apud SANTOS, 2007, p. 105) afirma que:

L'abjection é algo que provoca nojo. Por exemplo, você vê algo apodrecendo e quer vomitar. É 'abjeto' no nível da matéria. Também pode ser 
uma noção que diz respeito a questões morais - uma abjeção diante do crime, por exemplo. Mas é um sentimento extremamente forte, que é sobretudo uma revolta da pessoa contra uma ameaça externa da qual se quer manter distância, mas da qual se tem a impressão de que não é apenas uma ameaça externa, mas que pode nos ameaçar por dentro.

De acordo com Santos (2007), o abjeto é considerado como algo desprezível, baixo, ignóbil e repulsivo, mas que também pode causar um estranho fascínio. O indivíduo estabelece uma relação de repulsa e de atração pelo abjeto. Embora cause desconforto, nojo e revolta - principalmente, porque está não apenas no mundo exterior, mas também dentro de cada um -, é ambíguo e fascinante. Santos (2007, p. 107) considera que se trata "de uma parte sombria, é o vislumbre do nosso lado animal, no qual poucos ousam tocar, pois o contato fere, machuca, dilacera”.

Para Kristeva (1982), a primeira experiência do sujeito como ser, em relação ao mundo, é de plenitude, de conjunção total com o ambiente que o rodeia, sem nenhum tipo de fronteira. Entretanto, os limites entre o ser, o mundo e os outros precisam ser delineados. É aí que entra a abjeção: o sujeito começa a tentar se livrar e rejeitar o que parece não fazer parte dele mesmo.

"Expelir a mim mesmo". Numa escala muito maior de intensidade, esta é a sensação que provoca também o contato com um cadáver que, para Kristeva (1982), é o máximo da abjeção. A presença desse corpo morto provoca imediatamente a abjeção. Segundo Noëlle McAfee (2004), o cadáver significa que a fronteira entre morte e vida foi quebrada e que morte está "infectando"o corpo. Essa experiência revela, assim, a fragilidade da própria vida e a lembrança de que o sujeito deixará de existir.

O maior exemplo de abjeção está no que Kristeva (1982) denomina de "mãe abjeta"(abject mother). A abjeção começa quando a criança ainda se encontra em uma união imaginária com a sua mãe, muito antes de aprender a falar. Ao nascer, o indivíduo é separado do ventre de sua mãe, e aquele lugar onde estava se perde para sempre. Quando a memória dolorosa dessa perda retorna de alguma forma, configura-se, então, a abjeção, que continua assombrando o sujeito por toda a sua vida (SANTOS, 2007).

Nesse sentido, para Kristeva (1982), a abjeção não se configura como uma etapa passageira, mas, sim, permanece como um fantasma por toda a vida. Assim também é a morte: um fantasma o qual queremos manter longe, mas que sempre volta a nos ameaçar. A morte é não apenas fisicamente concreta, mas o medo que provoca pode nos corroer por dentro, como um veneno que vai tomando conta do corpo aos poucos.

É uma relação ambígua. Queremos negá-la e ignorá-la, mas ela está lá. Ambígua e abjeta também é a relação de Walmir Ayala com a morte. Ele parece sentir fascínio por ela; porém, ora se culpa por desejá-la, ora tenta reafirmar seu apreço pela vida. 


\section{O diário de Walmir Ayala}

Em 25 de outubro de 1977, Roland Barthes perdeu sua mãe. No dia seguinte, começou a escrever um diário de luto. É um texto fragmentado, no qual o autor expõe todo o seu sofrimento. Como afirma Ana Chiara (2014, p. 1), trata-se de um "livro silencioso", "um lamento em tom baixo, cada página branca, ocupada por frases curtas [...], secretando dor".

Durante quase dois anos, Barthes divide com o papel sua necessidade de solidão, seus altos e baixos e sua aproximação com a morte. Barthes foi vivendo seu luto dia a dia, e a escrita fazia parte desse processo. Em vez de sentir-se paralisado, o escritor trabalhava. Seu luto o acompanhava ou era um dos motivos para manterse ativo: "O 'Trabalho' pelo qual (dizem) saímos das grandes crises (amor, luto) não deve ser liquidado apressadamente; para mim, ele só se realiza na e pela escrita" (BARTHES, 2011, p. 129, grifo do autor). Assim, a perda da mãe o fazia mergulhar na escrita.

Walmir Ayala também escreveu seu diário de luto e, assim como Barthes, fez da escrita uma maneira de lidar com suas perdas. A morte que o afetou foi ainda mais abjeta, porque o corte com o corpo de sua mãe foi muito mais traumático e inesperado. Mas, ao contrário de Barthes, seu texto é excessivo. A morte e o luto são tratados de maneira abjeta: vomitados, jorrados em palavras que se repetem excessivamente ao longo de quase 400 páginas. O escritor se deprecia o tempo todo, diz clamar pela vida, para em seguida, chamar a morte. Como num jogo de esconde-esconde, não quer ser encontrado por ela, mas a procura constantemente.

Quando começou a escrever suas memórias, Ayala tinha somente 23 anos. Os textos contemplam o período de cinco anos e versam, principalmente, sobre os seguintes temas: morte, tristeza, solidão, amor, homossexualidade e poesia.

No diário de Walmir Ayala, de fato espaço de desabafo e resistência, como considera Lejeune (2014), há uma constante associação entre amor e morte, entre desejo de morrer, vergonha por ter esse desejo e vontade de rechaçá-lo. Em muitos momentos, há ainda referência ao pecado e ao cristianismo, consequência da criação católica que recebeu em Porto Alegre. Ayala encara Cristo como uma forte impressão da morte, uma tristeza absoluta da condição humana, que morre diante de seus olhos e não cessa de morrer (AyAlA, 1962, p. 11): "A mais viva impressão em relação à morte, até hoje, me vem da obrigatoriedade de beijar a imagem de Cristo descido da cruz, Cristo morto e martirizado, na Semana Santa" (Ayala, 1962, p. 136).

Como Barthes, Walmir Ayala também vive, em seu diário, o luto da perda de sua mãe. Mas, enquanto para Barthes, o luto é recente, e as memórias estão vivas, para Ayala, a perda está na infância e significou uma falta que parece nunca ser suprida. De acordo com Freud (2011, p. 47): 
o luto profundo, a reação à perda de uma pessoa amada, contêm o mesmo estado de ânimo doloroso, a perda de interesse pelo mundo externo - na medida em que este não faz lembrar o morto - , a perda capacidade de escolher um novo objeto de amor - em substituição ao pranteado - e o afastamento de toda e qualquer atividade que não tiver relação com a memória do morto.

Dessa forma, embora Ayala esteja sempre em busca do amor, ele nunca se concretiza. São tentativas frustradas, que acabam se mostrando como a procura por algo inatingível: "Porque só o amor importa, amor de belos, de corpos e almas em floração. Dizendo isto me nego tudo. Principalmente este direito de um grande amor cuja chave perdi com a morte de minha mãe" (AyAlA, 1962, p. 59-60).

Se não pode encontrar o amor, o poeta procura a morte. Amor e morte andam lado a lado no diário de Ayala - "Para mim o amor era frequentemente a possibilidade de descobrir um pouco mais o ramo subterrâneo que une o espírito à morte" (Ayala, 1962, p. 18). É como se morte e vida se completassem. Nessa busca, o poeta é sempre um inadaptado, não apenas porque vive um luto eterno, como também porque, embora fale abertamente sobre sua homossexualidade, existe a culpa do pecado, que carrega desde a infância.

O escritor diz acreditar na vida, mas essa crença é permeada por angústia e pela certeza de sua inutilidade: "A inexplicável angústia me põe deprimido. É porque reconheço a inutilidade da vida, eu que estou vinculado a ela por uma irresistível paixão. Sei que estou só, que ninguém espera nada de mim, e que eu não tenho nada para dar" (AyAlA, 1963, p. 13-14).

Porque não tem nada para dar, também não tem nada a receber. Por isso, Ayala parece acreditar que apenas a morte seria a solução para os seus problemas:

Mas sou um excessivo, e hoje senti uma premência de morte. Não realizar o amor seria morrer, perder pelo menos a urgência do plano a desfrutar. O que imagino: um céu. E estou interceptado de garras e antenas frias, crustáceo que se arrasta ante o voo de um pássaro. Mas não existe o pássaro. E sou o desamado irremediável (AyAlA, 1963, p. 60).

Walmir Ayala se vê como vítima do desamor: alguém que não teve o amor de sua mãe nem de seu pai - "Eu e meu pai sempre seremos estranhos um para o outro. [...] Assim ficamos como estranhos que se devem cortesias e isto é o maior remorso da minha vida" (AYALA, 1963, p. 48) - e que nunca se encontra nas relações amorosas, porque constantemente sente que não ama o suficiente ou que não é correspondido. Morrer seria pôr fim à urgência de encontrar um amor. Mas amar seria o paraíso. Como nada disso se concretiza, sua vida se transforma nesse eterno namoro com a morte: "Me interessa viver. $\mathrm{E}$ às vezes nem me interessa viver. Entendo cada vez mais os que se suicidam, embora esteja por uma questão 
de temor cada vez mais distante de uma atitude dessa natureza" (AyAlA, 1962, p. 26). Ou ainda: "Ajo diariamente como se estivesse para morrer. Não escrevo uma palavra que não seja pensando ser a minha última palavra” (AyALA, 1963, p. 38).

Ao mesmo tempo, o escritor afirma: "Não quero morrer! Sem dúvida o que mais me preocupa é o desejo irrefreável de ser um verdadeiro poeta" (AyAla, 1962, p. 89). Ayala vive, então, sua vida nesse paradoxo de ânsia pela vida e também pela morte. Nesse jogo, a escrita tem papel fundamental, pois é por meio dela que o escritor lida com o seu luto com suas escolhas de vida: "A esta altura digo, como D. H. Lawrence: 'escrevo por meu bem'. Sim, se escrevo é para não me perder, porque escrevendo me ponho em ordem. No fim é a busca da felicidade" (Ayala, 1962, p. 121). Uma felicidade nunca alcançada, mas sempre desejada. Assim, Walmir Ayala utiliza o diário se organizar - "me ponho em ordem" -, de forma que seja possível partir para a ação - "busca da felicidade" -, como aponta Lejeune (2014).

Mais que ofício, escrever é uma necessidade. Por meio do Diário, Ayala registra suas "minúcias e danos" (Ayala, 1976). Através de sua obra, o poeta se sente útil: "Cada dia penso: o que estou fazendo da minha vida? Em que sentido sou útil a mim e aos outros? Ainda não tenho discernimento disso. Mas de qualquer maneira não encontro coisa mais digna para mim, mas indispensável e fatal do que escrever" (AyAla, 1962, p. 24). O amor que não encontra na vida, concretizase na escrita: "o amor único, intransponível, insubstituível, este não me acontece. [...] Eu diria que a criação literária é a minha possibilidade de permanência no amor temporal e limitado" (AyALA, 1963, p. 18). A escrita o ajuda também a lidar com a melancolia, sua eterna companheira. Os trechos em que revela sua tristeza são inúmeros: "Hoje estou infeliz, tremendamente infeliz. Uma infelicidade sem dor, um remorso de viver uma vida tão digna de ser amada e vivida aos tropeços" (Ayala, 1963, p. 27). Segundo Freud (2011, p. 47):

A melancolia se caracteriza por um desânimo profundamente doloroso, uma suspensão do interesse pelo mundo externo, perda da capacidade de amar, inibição de toda atividade e um rebaixamento do sentimento de autoestima, que se expressa em autorrecriminações e autoinsultos, chegando até a expectativa delirante de punição. Esse quadro se aproximará mais de nossa compreensão se considerarmos que o luto revela os mesmos traços, exceto um: falta nele a perturbação do sentimento de autoestima.

Luto e melancolia, em geral, são dois sentimentos por vezes indissociáveis obviamente, há melancolia sem luto, mas dificilmente há luto sem melancolia e que se confundem ainda mais no texto de Ayala. O escritor quase sempre demonstra desânimo, afirma que quer amar, mas que pensa que não ama o suficiente e que nunca é correspondido. Em diversas entradas do diário, o poeta inicia seu texto de forma bastante melancólica, em forma de desabafo ou tratando de temas do cotidiano - como é característico deste tipo de escrita - que logo cul- 
minam em tristezas. Com o desenrolar da narrativa, esta, invariavelmente, acaba resvalando para o seu luto.

$E m 1^{\circ}$ de janeiro de 1960, Ayala afirma que está febril. No parágrafo seguinte, refere-se a um relacionamento com alguém cuja inicial é $\mathrm{C}$., sem dar muitos detalhes, para, em seguida escrever sobre sua solidão. $\mathrm{O}$ autor encerra esta entrada, trazendo, mais uma vez, o luto: "Um dia, e já vai longe, eu chorei longas noites perguntando: 'Minha mãe, por que não estás aqui? Por que me abandonaste'?" (Ayala, 1962, p. 82).

Exatamente um ano depois, em 1961, o poeta começa falando sobre seu sofrimento por causa de sua última experiência amorosa. A narrativa avança num desespero crescente, até que o autor afirma: "Estou como quem chora um filho distante, como quem acabou conscientemente de perder sua mãe. [...] agora começou a ruir tudo, só me resta esperar que as ruínas me forneçam solidão e memória" (Ayala, 1976, p. 59).

Poucos dias depois, em 19 de fevereiro do mesmo ano, Walmir Ayala se refere à melancolia que sente num fim de tarde no bairro de Santa Teresa, no Rio de Janeiro. Diz que sentirá uma saudade imensa de quando não estiver mais ali. Mais uma vez, a narrativa se encaminha para o luto: "A dor maior então é para quem fica, na dúvida ou esperança de um reencontro”.

De fato, a morte é o grande tema do diário de Walmir Ayala. E a relação abjeta que o poeta trava com a morte não se dá apenas nesse movimento de atração versus repulsa, mas também no interesse que parece demonstrar pela morte dos outros. Quando a mãe de seu grande amigo, o também escritor Lucio Cardoso, faleceu, Ayala escreveu:

Posso garantir que a fisionomia da morta (a mãe de Lúcio) me tranquilizou, tamanho o ar de espairecimento, de cisma sem angústia. As poucas vezes em que vira, antes, aquele corpo vivo e sem reação, aquela agonia muda prolongando-se, a consciência da inutilidade estampada na fisionomia esfumada. Agora me congratulo e respiro aliviado por ela (AyAlA, 1962, p. 57).

Tal interesse também aparece no Diário III, no qual o escritor descreve a morte de uma pessoa chamada Checa. Segundo ele, "uma irresistível e dolorosa curiosidade me prendia ao lado de seu leito de morte. Depois da fase dos gemidos começou aquela ofegância desesperada, como se o coração ansiasse sair pela boca para sobreviver independente do corpo arruinado" (Ayala, 1976, p. 49).

O volume três do diário de Walmir Ayala se encerra no dia 26 de dezembro de 1961. Sua última frase é: "Enfim, só redimimos com amor" (AyALA, 1976, p. 126). 


\section{Considerações finais}

Além de seus diários, o escritor publicou diversos livros, consagrando-se como crítico literário. A morte seria sempre um tema recorrente em suas obras. Seu segundo livro de poemas, publicado em 1957, chama-se Este sorrir, a morte. Em 1990, pouco tempo antes de falecer, Ayala escreveu o poema "Balada". Nele, o escritor reafirma a sua relação abjeta com a morte:

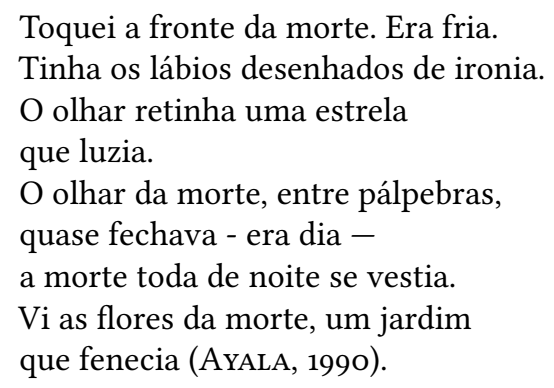

Como nos textos de seu diário, Ayala parece ver brilho na morte, mas também ironia e frieza. Um jardim que fenece: esta é metáfora que podemos encontrar constantemente na sua escrita. Walmir Ayala pode perceber as maravilhas da vida, mas elas são tomadas por sombras, que as fazem perder seu brilho.

De fato, a morte parece ter sido o fio condutor de boa parte de sua obra. Tema constantemente abordado em seus livros, em alguns momentos, o escritor parece relacioná-lo ao amor. Em seu diário, é evidente esta relação. "Enfim, só redimimos com amor", Walmir Ayala afirma na última frase de seu diário. Mas, para o escritor, a morte também significa a redenção.

No poema "Viola", diz Ayala: "Ai, não morras de amor, de amor não morre / o amor mata amor morosamente". Se te apraz dar socorro ao que socorre,/ aceita o que te mata eternamente / e não morras de amor, que amor não morre" (AyAlA, 2018).

Para Ayala, de amor não se morre, mas o amor mata o amor devagar. Amar parece ser morrer um pouco - um pouco de si se esvai no outro; o outro se perde em si ao amar; perdendo-se, a vida se esvai pouco a pouco. Entretanto, sem amor, a vida também é morte.

Importa ressaltar que, abordando a morte, ou qualquer outro assunto, Ayala o faz de maneira contundente, sincera e, como ele mesmo se define, excessiva. Nesse sentido, o escritor traz uma contribuição importante para a literatura: menos regras, mais paixão.

Por isso, como afirma o próprio poeta, ele era um representante de uma geração ainda não codificada. Talvez porque assombrado por imagens, que se traduzem em textos inquietantes, pessimistas, mas intrigantes e excessivamente sinceros. 


\section{Referências}

ArIÈs, Philippe. O homem diante da morte. Tradução de Luiza Ribeiro. São Paulo: Editora da Unesp, 2013.

Ayala, Walmir. Balada. Casa do Bruxo, [S.l.], [s.d.]. On-line. Disponível em: http: //www.casadobruxo.com.br/poesia/w/balada.htm. Acesso em: 13 dez. 2017.

Ayala, Walmir. Diário I - Difícil é o reino. Rio de Janeiro: GRD, 1962.

Ayala, Walmir. Diário II - O visível amor. Rio de Janeiro: José Alvaro, 1963.

Ayala, Walmir. Diário III - A fuga do arcanjo. Rio de Janeiro: Brasília, 1976.

Ayala, Walmir. Viola. Disponível em: https://www.poetris.com/sonetos/ walmir-ayala. Acesso em: 20 set. 2018.

Barthes, Roland. Diário de luto. Tradução de Leyla Perrone-Moisés. São Paulo: Martins Fontes, 2011.

Chiara, Ana Cristina. Barthes com Lacan: o fantasma do desejo no Diário de luto. Revista Trama Interdisciplinar, São Paulo, v. 5, n. 2, p. 52-57, 2014.

ChIARA, Ana Cristina. Pedro Nava, um homem no limiar. Rio de Janeiro: EdUERJ, 2001.

Foucault, Michel. O que é um autor. Tradução de Antônio Fernando Cascais, Eduardo Cordeiro. Lisboa: Vega, 1992.

Freud, Sigmund. Luto e melancolia. Tradução de Marilene Carone. São Paulo: Cosac Naify, 2011.

Kristeva, Julia. Powers of horror. Tradução de Leon S. Roudiez. Nova York: Columbia University Press, 1982.

Lejeune, Phillipe. O pacto autobiográfico: de Rousseau à Internet. Tradução de Jovida Maria Gerheim Noronha e Maria Ines Coimbra Guedes. Belo Horizonte: Editora da UFMG, 2014.

McafeE, Noëlle. Fulia Kristeva. Nova York; Londres: Routledge, 2004.

PAIXão, Roseane Cristina da. Quando a arte imita a vida: ficção e memória nos diários de Lucio Cardoso e Walmir Ayala. Dissertação (Mestrado em Letras) Universidade Federal de São João Del Rey, São João Del Rey, 2011.

Rodrigues, José Carlos. Tabu da morte. Rio de Janeiro: Achiamé, 1983.

Santos, Daniele Ribeiro dos. Do realismo sujo ao realismo vazio: um estudo comparativo entre a ficção de Rubem Fosneca e Pedro Juan Gutiérrez. (Doutorado em Letras) - Universidade do Estado do Rio de Janeiro, Rio de Janeiro, 2007. 
Recebido em 6 de abril de 2018.

Aprovado em 17 de setembro de 2018 .

\section{Resumo/Abstract/Resumen}

\section{Luto e escrita no diário de Walmir Ayala}

\section{Daniele Ribeiro Fortuna}

Este artigo analisa os três volumes do diário do escritor Walmir Ayala - escritos no final dos anos 1950 e publicados nas décadas de 1960 e $1970-$, principalmente no que diz respeito à sua relação com a morte. Com uma vasta obra, atualmente pouco conhecida do grande público, Ayala lançou diversos livros, entre romances, contos, coletâneas de poesia e peças de teatro. Sua escrita é marcada por um intenso interesse pela morte. Tal interesse parece ter relação com a perda de sua mãe, que morreu quando ele tinha apenas quatro anos. Em seus escritos, o próprio escritor revela que a perda de sua mãe teve uma importância crucial na sua trajetória. Esta perda é evidente em vários trechos de seu diário. Organizado em trechos fragmentados - como é comum nesse tipo de obra -, o diário apresenta inúmeros trechos nos quais o autor trata de solidão e luto. Antes de analisar o diário, porém, apresentamos um breve resumo da vida do escritor. Em seguida, abordamos a questão da morte, explicitando como a sociedade lida com ela atualmente. Posteriormente, refletimos sobre o caráter abjeto da morte. Por fim, tratamos do diário de Walmir Ayala. Dividido em três volumes, que somam quase quatrocentas páginas, a obra revela o estreito vínculo do escritor com a morte. Como referencial teórico, são utilizadas, principalmente, as obras de Ariès (2013), Kristeva (1982) e Rodrigues (1983).

Palavras-chave: Walmir Ayala, diário, morte.

\section{Mourning and writing in Walmir Ayala's diary}

\section{Daniele Ribeiro Fortuna}

This article analyzes Walmir Ayala's three volume diary - written in the late 1950 and published in the decades of 1960 and 1970 - especially with regard to his relationship with death. With a vast work, currently little known to the general public, Ayala published several books, including novels, short stories, poetry collections and plays. His writing is marked by an intense interest in death. Such interest seems to be related to the loss of his mother, who died when he was only four. In his writings, the writer himself reveals that this loss of his mother was of crucial importance in his career. This loss is evident in several passages in his diary. Organized in fragmented passages - as is common in this type of work 
- the diary presents numerous passages in which the author deals with solitude and mourning. Before analyzing the diary, however, we present a brief summary of the writer's life. Next, we address the issue of death, explaining how society deals with it today. Subsequently, we reflect on the abject character of death. Finally, we deal with Walmir Ayala's diary. Divided into three volumes, which total almost four hundred pages, the work reveals the writer's close bond with death. As a theoretical reference, the works of Ariès (2013), Kristeva (1982) and Rodrigues (1983) are mainly used.

Keywords: Walmir Ayala, diary, death.

\section{Luto y escritura en el diario de Walmir Ayala}

\section{Daniele Ribeiro Fortuna}

Este artículo analiza los tres volúmenes del diario del escritor Walmir Ayala - escritos a finales de los años 50 y publicados en las décadas de 1960 y $1970-$, principalmente en lo que se refiere a su relación con la muerte. Con una vasta obra, actualmente poco conocida por el gran público, Ayala publicó diversos libros: novelas, cuentos, colecciones de poesía y obras de teatro. Su escritura está marcada por un intenso interés por la muerte. Tal interés parece tener relación con la pérdida de su madre, que murió cuando tenía solo cuatro años. En sus escritos, el propio escritor revela que la pérdida de su madre tuvo una importancia crucial en su trayectoria. Esta pérdida es evidente en varios fragmentos de su diario. Organizado en fragmentos - como es común en este tipo de obra -, el diario presenta innumerables fragmentos en los que el autor trata de soledad y duelo. Antes de analizar el diario, sin embargo, presentamos un breve resumen de la vida del escritor. A continuación, abordamos la cuestión de la muerte, explicitando cómo la sociedad trata con ella actualmente. Posteriormente, reflexionamos sobre el carácter abyecto de la muerte. Por último, tratamos del diario de Walmir Ayala. Dividido en tres volúmenes, que suman casi cuatrocientas páginas, la obra revela el estrecho vínculo del escritor con la muerte. Como referente teórico, se utilizan principalmente las obras de Ariès (2013), Kristeva (1982) y Rodrigues (1983).

Palabras clave: Walmir Ayala, diario, muerte. 